\title{
Host-specific Dactylogyrus parasites revealing new insights on the historical biogeography of Northwest African and Iberian cyprinid fish
}

Andrea Šimková ${ }^{*}$, Michal Benovics ${ }^{1}$ Imane Rahmouni ${ }^{2}$ and Jasna Vukić ${ }^{3}$

\begin{abstract}
Background: Host specificity in parasites represents the extent to which a parasite's distribution is limited to certain host species. Considering host-specific parasites of primarily freshwater fish (such as gill monogeneans), their biogeographical distribution is essentially influenced by both evolutionary and ecological processes. Due to the limited capacity for historical dispersion in freshwater fish, their specific coevolving parasites may, through historical host-parasite associations, at least partially reveal the historical biogeographical routes (or historical contacts) of host species. We used Dactylogyrus spp., parasites specific to cyprinid fish, to infer potential historical contacts between Northwest African and European and Asian cyprinid faunas. Using phylogenetic reconstruction, we investigated the origin(s) of host-specific Dactylogyrus spp. parasitizing Northwest African and Iberian cyprinid species.

Results: In accordance with hypotheses on the historical biogeography of two cyprinid lineages in Northwest Africa, Barbini (Luciobarbus) and Torini (Carasobarbus), we demonstrated the multiple origins of Northwest African Dactylogyrus. Dactylogyrus spp. of Carasobarbus spp. originated from Asian cyprinids, while Dactylogyrus spp. of Luciobarbus spp. originated from European cyprinids. This indicates the historical Northern route of Dactylogyrus spp. dispersion to Northwest African Luciobarbus species rather than the Southern route, which is currently widely accepted for Luciobarbus. In addition, both Northwest African cyprinid lineages were also colonized by Dactylogyrus marocanus closely related to Dactylogyrus spp. parasitizing African Labeo spp., which suggests a single host switch from African Labeonini to Northwest African Luciobarbus. We also demonstrated the multiple origins of Dactylogyrus spp. parasitizing Iberian Luciobarbus species. One Iberian Dactylogyrus group was phylogenetically closely related to Dactylogyrus of Moroccan Carasobarbus, while the second was related to Dactylogyrus of Moroccan Luciobarbus.
\end{abstract}

Conclusions: Our study confirms the different origins of two Northwest African cyprinid lineages. It suggests several independent historical contacts between European Iberian Luciobarbus and two lineages of Northwest African cyprinids, these contacts associated with host switches of Dactylogyrus parasites.

Keywords: Cyprinids, Dactylogyrus, Historical biogeography, Host specificity, Iberia, Northwest Africa

\footnotetext{
*Correspondence: simkova@sci.muni.cz

${ }^{1}$ Department of Botany and Zoology, Faculty of Science, Masaryk University,

Kotlářská 2, 61137 Brno, Czech Republic

Full list of author information is available at the end of the article
} 


\section{Background}

Primary freshwater fish are supposed to be intolerant to salinity, and thus their dispersal is restricted to freshwater routes only. Because of such limited dispersion mechanisms, relationships between fish lineages may reflect relationships between different areas; therefore, freshwater fish are suitable for studies of historical biogeography [1]. Over evolutionary time, the diversity of parasite communities of such freshwater fish is shaped by coevolutionary and historical biogeographical processes (e.g. [2, 3]). However, over ecological time, parasite biogeography is also influenced by the temporal and spatial variability in ecological factors $[4,5]$.

Concerning freshwater fish, the biogeography of their helminth parasites was shown to reflect historical processes related to the current distribution of their hosts. For example, helminth diversity in Mexican freshwater fishes is determined by the historical and contemporary biogeography of their hosts [6]. The distribution of the metazoan parasites of the sturgeon fish (Acipenseridae) was shown to be in accord with the historical biogeographical routes of these fishes [7].

The host specificity of fish parasites (i.e. the extent to which a parasite's distribution is limited to certain host species) seems to be their most important characteristic, with the potential to reflect historical host-parasite associations and to indicate the historical biogeographical routes of hosts. McDowell [8] showed that parasites not coevolving with their galaxioid fish hosts (i.e. Galaxiidae and Retropinnidae) do not support a vicariance biogeography for galaxioid fish. However, if the host specificity of a parasite group is high, then the phylogenetic and biogeographical relationships between hosts and parasites may be mutually illuminating [1].

Gill monogeneans of the highly diversified genus Dactylogyrus Diesing, 1850 are species-specific to their cyprinid host species (with some rare exceptions). According to Šimková et al. [9], Dactylogyrus species often exhibit strict host specificity (i.e. they are specific to a single cyprinid species), congeneric host specificity (i.e. they are specific to congeneric cyprinid species), or phylogenetic host specificity (i.e. they are specific to phylogenetically closely related cyprinid species). The distribution of Dactylogyrus species on their cyprinid hosts reflects the evolutionary history of these fishes [10]. The evolution of Dactylogyrus lineages is associated with different cyprinid lineages, and the presence of the same Dactylogyrus species on the representatives of different cyprinid lineages (i.e. in cyprinid species with high divergence but living in the same biogeographical area) is only accidental $[9,10]$. Little is known about Dactylogyrus of cyprinid species living in the Mediterranean region. However, some studies are suggesting that due to high host specificity, the endemism of Dactylogyrus parasites follows the endemism of their cyprinid host species. Such endemic Dactylogyrus were documented for Luciobarbus Heckel, 1843 from the Iberian Peninsula [11], for Luciobarbus from Northwest Africa [12], and for cyprinids living in Lake Mikri Prespa (northern Greece) [13, 14].

Cyprinids are primarily freshwater fish with their native distribution in Europe, Asia, Africa and North America. The different cyprinid lineages exhibit different biogeographical distributions across continents [15]. One of the lineages, the subfamily Cyprininae, was recently revised by Yang et al. [16] to include 11 tribes. Most representatives of this subfamily inhabit waters of southern Eurasia and Africa. Of the four evolutionary lineages (i.e. tribes) of Cyprininae present in Africa, two have been recognized in Northwestern Africa. The first lineage includes hexaploid genera of large-sized barbels (Carasobarbus Karaman, 1971, Pterocapoeta Günther, 1902 and Labeobarbus Rüppel, 1835) belonging to the tribe Torini (this tribe includes large-sized barbels from Asia and Africa). The second lineage is represented by tetraploid Luciobarbus belonging to the tribe Barbini (this tribe includes the taxa distributed in Eurasia and Northwest Africa). Different origins and different dispersal events from Eurasia to Africa were proposed for these lineages. The two genera which are widespread in Northwest Africa, Carasobarbus and Luciobarbus, have disjunct distributions. Carasobarbus is distributed in Northwest Africa and the Middle East, while Luciobarbus is distributed in West Asia, Northwest Africa, Greece and the Iberian Peninsula. The largesized African hexaploids are not monophyletic like the Moroccan Carasobarbus cluster with Middle East Carasobarbus, suggesting that the diversification of African hexaploids preceded the separation between the Middle East and Northwest African hexaploids $[16,17]$. Tsigenopoulos et al. [17] suggested that the large hexaploids invaded Africa through the land bridge between Africa and Asia (via the Arabian tectonic Plate) formed in the Middle Miocene (about 13 MYA). Using molecular calibration, they calculated that the splitting of the African hexaploids from their Asian ancestors and subsequently the beginning of the diversification of the African hexaploid lineage occurred in the Late Miocene. The genus Luciobarbus is paraphyletic, as the clade also includes the genus Capoeta Güldenstädt, 1773. Concerning Luciobarbus species in Northwest Africa, they do not form a monophyletic group either, as two Northwest African species cluster with Iberian species [16, 18-20]. Concerning Luciobarbus in the Iberian Peninsula, three main hypotheses were proposed for their origin; some of them have direct implications for the origin of this genus in Northwest Africa. First, Banarescu [21] and 
Almaça [22] proposed that the Iberian Peninsula was colonized from the North before the formation of the Pyrenees. Based on this hypothesis, barbels from the Iberian Peninsula are evolutionarily closer to European and African barbels than to Asian species. Secondly, Doadrio [23] proposed that Luciobarbus colonized Iberia from Africa via southern Spain at the Miocene-Pliocene boundary (about 5 MYA) after the Messinian salinity crisis of the Mediterranean Sea. Following this hypothesis, barbels from the Iberian Peninsula are phylogenetically closer to Asian and North African barbels than to those of central Europe. Thirdly, Bianco [24] proposed that the distribution of Luciobarbus be explained by the freshwater phase (the so-called Lago Mare phase) of the Mediterranean Sea, which supposedly followed the Messinian salinity crisis. Following this hypothesis, Iberian barbels are more related to those of the Balkans than to central European species. However, this third hypothesis has been rejected by many authors by both geological data and the estimation of the time of diversification of freshwater fish species [25] according to the finding of fossils preceding the given geological period. Tsigenopoulos et al. [26] and Yang et al. [16] showed that most Luciobarbus species from Northwest Africa are more closely related to Luciobarbus from the Middle East than to Luciobarbus from the Iberian Peninsula.

The aim of this study was to reconstruct the phylogeny of gill parasites of the genus Dactylogyrus, monogeneans specific to cyprinid fish species, to (i) investigate the phylogenetic position of African Dactylogyrus parasites in relation to European and Asian Dactylogyrus lineages with a special focus on the origin(s) of Dactylogyrus parasitizing Northwest African and Iberian cyprinid fish species, and (ii) infer potential scenarios of the Dactylogyrus colonization of Northwest African and Iberian cyprinids in relation to their historical biogeography.

\section{Methods}

\section{Dactylogyrus species}

For this study, Dactylogyrus species were sampled from cyprinid species in Morocco and the Iberian Peninsula. Other Dactylogyrus spp. collected from cyprinid species sampled in Europe (the Balkan Peninsula, including Greece and Bosnia and Herzegovina, and central Europe, represented by the Czech Republic) and Africa (Senegal) were included in this study. These Dactylogyrus spp. were selected to recover representatives parasitizing different cyprinid lineages and also to include species potentially phylogenetically related to the Dactylogyrus spp. collected in Northwest Africa and the Iberian Peninsula. In addition, Dactylogyrus species from Asian cyprinid species, for which molecular data (i.e. the sequences of 28S DNA) were available in GenBank, were included in the analyses. The list of studied Dactylogyrus species, their host species, locality of collection, and accession numbers are presented in Table 1.

In the field, Dactylogyrus species were removed from fish gills during fish dissection (following Ergens \& Lom [27]), placed on slides, covered with a coverslip, and fixed in a mixture of glycerine and ammonium picrate (GAP). The identification was performed on the basis of the size and shape of the sclerotized parts of the attachment organ, the haptor, and the sclerotized parts of the reproductive organs, following the original descriptions [11, 12, 28-32]. Morphological examination was performed using an Olympus BX51 light microscope equipped with phase contrast and differential interference contrast. Some specimens of each Dactylogyrus species were bisected; one-half of the body (usually the anterior one with reproductive organs) was mounted on a slide for species identification, and the other was individually preserved in 96\% ethanol for DNA extraction.

\section{DNA extraction, amplification and sequencing}

Dactylogyrus species collected from cyprinids in Africa and Europe were sequenced to obtain partial sequences of $28 \mathrm{~S}$ rDNA and partial sequences of $18 \mathrm{~S}$ rDNA and the ITS1 region. Dactylogyrus specimens were individually removed from ethanol and dried by using a vacuum centrifuge. Genomic DNA extraction was performed following a standard protocol (DNeasy Blood \& Tissue Kit, Qiagen, Hilden, Germany). Partial $28 \mathrm{~S}$ rDNA was amplified using the forward primer $\mathrm{C} 1{ }^{2}\left(5^{\prime}\right.$-ACC CGC TGA ATT TAA GCA-3') and the reverse primer D2 (5'-TGG TCC GTG TTT CAA GAC-3') [33]. PCR followed the protocol included in Šimková et al. [34]. Partial $18 \mathrm{~S}$ rDNA and the entire ITS1 region were amplified in one round using the primers S1 (5' ${ }^{\prime}$ ATT CCG ATA ACG AAC GAG ACT-3') and IR8 (5'-GCT AGC TGC GTT CTT CAT CGA-3') [35] that anneal to $18 \mathrm{~S}$ and $5.8 \mathrm{~S}$ rDNA, respectively. Each amplification reaction for partial 18S rDNA and the ITS1 region was performed in a final volume of $15 \mu \mathrm{l}$, containing $1.5 \mathrm{U}$ of Taq polymerase, $1 \times$ buffer, $1.5 \mathrm{mM} \mathrm{MgCl} 2,0.2 \mathrm{mM}$ of each dNTP, $0.5 \mu \mathrm{M}$ of each primer, and $2.5 \mu \mathrm{l}$ of DNA $(20 \mathrm{ng} / \mu \mathrm{l})$. PCR was carried out using the following steps: $2 \mathrm{~min}$ at $94{ }^{\circ} \mathrm{C}$, followed by 40 cycles of $1 \mathrm{~min}$ at $94{ }^{\circ} \mathrm{C}, 1 \mathrm{~min}$ at $53{ }^{\circ} \mathrm{C}$ and $1 \mathrm{~min} 30 \mathrm{~s}$ at $72{ }^{\circ} \mathrm{C}$, and $10 \mathrm{~min}$ of final elongation at $72{ }^{\circ} \mathrm{C}$. The PCR products were checked on $1.5 \%$ agarose gel, purified using ExoSAP-IT kit (Ecoli, SK) following a standard protocol and directly sequenced using the PCR primers and BigDye Terminator Cycle sequencing kit (Applied Biosystems, Foster City, CA). Sequencing was carried out using an ABI 3130 Genetic Analyser (Applied Biosystems). Sequences were analysed 
Table 1 List of Dactylogyrus species, their cyprinid host species, cyprinid phylogeny, country of collection and GenBank accession numbers for sequences used in the phylogenetic analyses

\begin{tabular}{|c|c|c|c|c|c|c|}
\hline Dactylogyrus species & Cyprinid host species & $\begin{array}{l}\text { Cyprinid } \\
\text { subfamily }\end{array}$ & $\begin{array}{l}\text { Cyprinid } \\
\text { tribe }\end{array}$ & $\begin{array}{l}\text { Country of } \\
\text { collection }\end{array}$ & $\begin{array}{l}\text { GenBank ID } \\
(28 \mathrm{~S} \text { rDNA) }\end{array}$ & $\begin{array}{l}\text { GenBank ID } \\
\text { (18S rDNA with ITS1) }\end{array}$ \\
\hline D. bicornis Malewitzkaja, $1941^{\text {a }}$ & $\begin{array}{l}\text { Rhodeus meridionalis Karaman, } \\
1924\end{array}$ & Acheilognathinae & - & Greece & KY629345 & - \\
\hline D. labei Musselius \& Gussev, 1976 & Catla catla (Hamilton, 1822) & Cyprininae & Labeonini & India & $J \times 566720$ & - \\
\hline D. quanfami Ha Ky, 1971 & $\begin{array}{l}\text { Cirrhinus molitorella } \\
\text { (Valenciennes, 1844) }\end{array}$ & Cyprininae & Labeonini & China & EF100536 & - \\
\hline $\begin{array}{l}\text { D. lenkoranoides El Gharbi, } \\
\text { Renaud \& Lambert, } 1992\end{array}$ & $\begin{array}{l}\text { Luciobarbus guiraonis } \\
\text { (Steindachner, 1866) }\end{array}$ & Cyprininae & Barbini & Spain & KY629346 & - \\
\hline $\begin{array}{l}\text { D. bocageii Alvarez Pellitero, } \\
\text { Simón Vicente \& González } \\
\text { Lanza, } 1981\end{array}$ & $\begin{array}{l}\text { Luciobarbus bocagei } \\
\text { (Steindachner, 1864) }\end{array}$ & Cyprininae & Barbini & Portugal & KY629347 & - \\
\hline D. balistae Simón Vicente, 1981 & Luciobarbus bocagei & Cyprininae & Barbini & Portugal & - & KY629344 \\
\hline $\begin{array}{l}\text { D. mascomai El Gharbi, } \\
\text { Renaud \& Lambert, } 1992\end{array}$ & Luciobarbus guiraonis & Cyprininae & Barbini & Spain & KY629348 & - \\
\hline $\begin{array}{l}\text { D. linstowoides El Gharbi, } \\
\text { Renaud \& Lambert, } 1992\end{array}$ & Luciobarbus guiraonis & Cyprininae & Barbini & Spain & KY629349 & KY629329 \\
\hline $\begin{array}{l}\text { D. legionensis González Lanza \& } \\
\text { Alvarez Pellitero, } 1982\end{array}$ & Luciobarbus guiraonis & Cyprininae & Barbini & Spain & KY629350 & KY629330 \\
\hline $\begin{array}{l}\text { D. andalousiensis El Gharbi, } \\
\text { Renaud \& Lambert, } 1992\end{array}$ & Luciobarbus sclateri Günther, 1868 & Cyprininae & Barbini & Portugal & KY629351 & KY629331 \\
\hline $\begin{array}{l}\text { D. zatensis El Gharbi, Birgi \& } \\
\text { Lambert, } 1994\end{array}$ & Carasobarbus fritschii Günther, 1874 & Cyprininae & Torini & Morocco & KY629352 & KY629335 \\
\hline $\begin{array}{l}\text { D. volutus El Gharbi, Birgi \& } \\
\text { Lambert, } 1994\end{array}$ & Carasobarbus fritschii & Cyprininae & Torini & Morocco & KY629353 & KY629334 \\
\hline $\begin{array}{l}\text { D. kulindrii El Gharbi, Birgi \& } \\
\text { Lambert, } 1994\end{array}$ & Carasobarbus fritschii & Cyprininae & Torini & Morocco & KY629354 & KY629336 \\
\hline 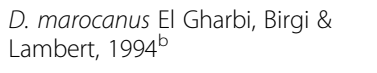 & Carasobarbus fritschii, & Cyprininae & Torini & Morocco & KY629355 & KY629333 \\
\hline $\begin{array}{l}\text { D. scorpius Rahmouni, } \\
\text { Řehulková \& Šimková, } 2017\end{array}$ & $\begin{array}{l}\text { Luciobarbus rifensis Doadrio, } \\
\text { Casal-Lopéz \& Yahyaoui, } 2015\end{array}$ & Cyprininae & Barbini & Morocco & KY553860 & KY578023 \\
\hline $\begin{array}{l}\text { D. benhoussai Rahmouni, } \\
\text { Řehulková \& Šimková, } 2017\end{array}$ & $\begin{array}{l}\text { Luciobarbus moulouyensis } \\
\text { (Pellegrin, 1924) }\end{array}$ & Cyprininae & Barbini & Morocco & KY553862 & KY578025 \\
\hline $\begin{array}{l}\text { D. varius Rahmouni, } \\
\text { Rehulková \& Šimková, } 2017\end{array}$ & $\begin{array}{l}\text { Luciobarbus maghrebensis Doadrio, } \\
\text { Perea \& Yahyaoui, } 2015\end{array}$ & Cyprininae & Barbini & Morocco & KZ553863 & KY578026 \\
\hline $\begin{array}{l}\text { D. falsiphallus Rahmouni, } \\
\text { Rehulková \& Šimková, } 2017\end{array}$ & Luciobarbus maghrebensis & Cyprininae & Barbini & Morocco & KZ553861 & KY578024 \\
\hline $\begin{array}{l}\text { D. atlasensis El Gharbi, Birgi \& } \\
\text { Lambert, } 1994\end{array}$ & $\begin{array}{l}\text { Luciobarbus pallaryi } \\
\text { (Pellegrin, 1919) }\end{array}$ & Cyprininae & Barbini & Morocco & KY629356 & KY629337 \\
\hline $\begin{array}{l}\text { D. fimbriphallus El Gharbi, } \\
\text { Birgi \& Lambert, } 1994\end{array}$ & $\begin{array}{l}\text { Luciobarbus massaensis } \\
\text { (Pellegrin, 1922) }\end{array}$ & Cyprininae & Barbini & Morocco & KY629357 & KY629332 \\
\hline Dactylogyrus sp. 1 & $\begin{array}{l}\text { Enteromius niokoloensis } \\
\text { (Daget, 1959) }\end{array}$ & Cyprininae & Smiliogastrini & Senegal & KY629358 & - \\
\hline D. aspili Birgi \& Lambert, 1987 & $\begin{array}{l}\text { Enteromius macrops } \\
\text { (Boulenger, 1911) }\end{array}$ & Cyprininae & Smiliogastrini & Senegal & KY629359 & - \\
\hline $\begin{array}{l}\text { D. leonis Musilová, Řehulková \& } \\
\text { Gelnar, } 2009\end{array}$ & Labeo coubie Rüppell, 1832 & Cyprininae & Labeonini & Senegal & KY629360 & - \\
\hline D. oligospirophallus Paperna, 1973 & Labeo coubie & Cyprininae & Labeonini & Senegal & KY629361 & - \\
\hline D. brevicirrus Paperna, 1973 & Labeo parvus Boulenger, 1902 & Cyprininae & Labeonini & Senegal & KY629362 & - \\
\hline D. senegalensis Paperna, 1969 & $\begin{array}{l}\text { Labeo senegalensis } \\
\text { Valenciennes, } 1842\end{array}$ & Cyprininae & Labeonini & Senegal & KY629363 & - \\
\hline $\begin{array}{l}\text { D. titus Guégan, } \\
\text { Lambert \& Euzet, } 1988\end{array}$ & Labeo senegalensis & Cyprininae & Labeonini & Senegal & KY629364 & - \\
\hline $\begin{array}{l}\text { D. falcilocus Guegan, Lambert \& } \\
\text { Euzet, } 1988\end{array}$ & Labeo coubie & Cyprininae & Labeonini & Senegal & KY629365 & - \\
\hline D. vastator Nybelin, 1924 & Carassius gibelio (Bloch, 1782) & Cyprininae & Cyprinini & Czech Republic & KY629366 & KY201103 \\
\hline
\end{tabular}


Table 1 List of Dactylogyrus species, their cyprinid host species, cyprinid phylogeny, country of collection and GenBank accession numbers for sequences used in the phylogenetic analyses (Continued)

\begin{tabular}{|c|c|c|c|c|c|c|}
\hline Dactylogyrus species & Cyprinid host species & $\begin{array}{l}\text { Cyprinid } \\
\text { subfamily }\end{array}$ & $\begin{array}{l}\text { Cyprinid } \\
\text { tribe }\end{array}$ & $\begin{array}{l}\text { Country of } \\
\text { collection }\end{array}$ & $\begin{array}{l}\text { GenBank ID } \\
(28 \mathrm{~S} \text { rDNA) }\end{array}$ & $\begin{array}{l}\text { GenBank ID } \\
\text { (18S rDNA with ITS1) }\end{array}$ \\
\hline $\begin{array}{l}\text { D. extensus Mueller \& } \\
\text { Van Cleave, } 1932\end{array}$ & Cyprinus carpio Linnaeus, 1758 & Cyprininae & Cyprinini & Czech Republic & AY553629 & - \\
\hline $\begin{array}{l}\text { D. inexpectatus Isjumova in } \\
\text { Gussev, } 1955\end{array}$ & Carassius gibelio & Cyprininae & Cyprinini & Czech Republic & AJ969945 & - \\
\hline D. anchoratus (Dujardin, 1845) & Carassius gibelio & Cyprininae & Cyprinini & Czech Republic & KY201116 & KY201102 \\
\hline Dactylogyrus sp. AC2012 & Cyprinus carpio & Cyprininae & Cyprinini & India & JQ926198 & - \\
\hline D. dyki Ergens \& Lucky, 1959 & Barbus barbus (Linnaeus, 1758) & Cyprininae & Barbini & Czech Republic & KY629367 & KY629338 \\
\hline $\begin{array}{l}\text { D. crivellius Dupont \& } \\
\text { Lambert, } 1986\end{array}$ & $\begin{array}{l}\text { Barbus peloponesius } \\
\text { Valenciennes, } 1842\end{array}$ & Cyprininae & Barbini & Greece & KY629368 & KY629339 \\
\hline D. carpathicus Zachvatkin, 1951 & Barbus barbus & Cyprininae & Barbini & Czech Republic & KY201111 & KY201098 \\
\hline Dactylogyrus sp. 2 & $\begin{array}{l}\text { Luciobarbus albanicus } \\
\text { (Steindachner, 1870) }\end{array}$ & Cyprininae & Barbini & Greece & KY201114 & KY201100 \\
\hline Dactylogyrus sp. 3 & $\begin{array}{l}\text { Luciobarbus graecus } \\
\text { (Steindachner, 1895) }\end{array}$ & Cyprininae & Barbini & Greece & KY201115 & KY201101 \\
\hline $\begin{array}{l}\text { D. prespensis Dupont \& Lambert, } \\
1986\end{array}$ & Barbus prespensis Karaman, 1924 & Cyprininae & Barbini & Greece & KY201110 & KY201096 \\
\hline D. petenyi Kastak, 1957 & $\begin{array}{l}\text { Barbus balcanicus Kotlík, } \\
\text { Tsigenopoulos, Ráb \& Berrebi, } 2002\end{array}$ & Cyprininae & Barbini & Greece & - & KY201097 \\
\hline D. malleus Linstow, 1877 & Barbus barbus & Cyprininae & Barbini & Czech Republic & KY201112 & KY201099 \\
\hline D. vistulae Prost, 1957 & Squalius prespensis (Fowler, 1977) & Leuciscinae & - & Albania & KY629369 & KY629640 \\
\hline D. fallax Wagener, 1857 & Vimba vimba (Linnaeus, 1758) & Leuciscinae & - & Czech Republic & KY629370 & KY629341 \\
\hline D. cornu Linstow, 1878 & Vimba vimba & Leuciscinae & - & Czech Republic & KY629371 & KY629342 \\
\hline D. borealis Nybelin, 1937 & Phoxinus sp. & Leuciscinae & - & $\begin{array}{l}\text { Bosnia and } \\
\text { Herzegovina }\end{array}$ & KY629372 & KY629343 \\
\hline $\begin{array}{l}\text { D. nanus Dogiel \& } \\
\text { Bychowsky, } 1934\end{array}$ & Rutilus rutilus (Linnaeus, 1758) & Leuciscinae & - & Czech Republic & AJ969942 & AJ564145 \\
\hline D. sphyrna Linstow, 1878 & Rutilus rutilus & Leuciscinae & - & Czech Republic & AJ969943 & AJ564154 \\
\hline D. suecicus Nybelin, 1937 & Rutilus rutilus & Leuciscinae & - & Czech Republic & KY629373 & - \\
\hline D. crucifer Wagener, 1857 & Rutilus rutilus & Leuciscinae & - & Czech Republic & KY629374 & AJ564120 \\
\hline D. wunderi Bychowsky, 1931 & Abramis brama (Linnaeus, 1758) & Leuciscinae & - & Czech Republic & KY629375 & AJ564164 \\
\hline D. cryptomeres Bychowsky, 1943 & Gobio gobio (Linnaeus, 1758) & Gobioninae & - & Czech Republic & AJ969947 & - \\
\hline D. lamellatus Achmerow, 1952 & $\begin{array}{l}\text { Ctenopharyngodon idella } \\
\text { (Valenciennes, 1844) }\end{array}$ & Xenocyprinae & - & China & AY307019 & - \\
\hline $\begin{array}{l}\text { D. hypophthalmichthys } \\
\text { Akhmerov, } 1952\end{array}$ & $\begin{array}{l}\text { Hypophthalmichthys molitrix } \\
\text { (Valenciennes, 1844) }\end{array}$ & Xenocyprinae & - & China & EF100532 & - \\
\hline Dactylogyrus sp. (YY) & $\begin{array}{l}\text { Hypophthalmichthys nobilis } \\
\text { (Richardson, 1845) }\end{array}$ & Xenocyprinae & - & China & EF100538 & - \\
\hline D. parabramis Akhmerov, 1952 & $\begin{array}{l}\text { Megalobrama terminalis } \\
\text { (Richardson, 1846) }\end{array}$ & Xenocyprinae & - & China & EF100534 & - \\
\hline D. petruschewskyi Gussev, 1955 & $\begin{array}{l}\text { Megalobrama amblycephala } \\
\text { Yih, } 1955\end{array}$ & Xenocyprinae & - & China & AY548927 & - \\
\hline D. pekinensis Gussev, 1955 & Megalobrama amblycephala & Xenocyprinae & - & China & EF100535 & - \\
\hline
\end{tabular}

a Morphologically identical D. bicornis was also found on Rhodeus amarus (Bloch, 1782) from the Czech Republic; the sequence data are not available ${ }^{b}$ Morphologically and genetically identical $D$. marocanus was also collected from Pterocapoeta maroccana, Luciobarbus ksibii, Luciobarbus zayanensis

using Sequencher 4.7 (Gene Codes Corp., Ann Arbor, MI, USA), and new sequences were deposited in GenBank (see Table 1 for accession numbers). The sequences of other Dactylogyrus species parasitizing European and Asian cyprinid species were retrieved in GenBank (Table 1) and were used for phylogenetic analyses.

\section{Phylogenetic analyses}

The first alignment included the partial 28S rDNA sequences of 55 Dactylogyrus species. Among them, 36 were newly sequenced for this study. The sequences of the other 19 Dactylogyrus species as well as the sequences of three species of the Dactylogyridae 
(Euryhaliotrematoides pirulum Plaisance \& Kritsky, 2004, Euryhaliotrematoides triangulovagina Yamaguti, 1968 and Aliatrema cribbi Plaisance \& Kritsky, 2004 with accession numbers AY820618, AY820619 and AY820612, respectively), used as the outgroup in the phylogenetic analyses, were retrieved from GenBank. The second alignment included the partial $18 \mathrm{~S}$ rDNA sequences and the ITS1 region of 26 Dactylogyrus species belonging to Dactylogyrus lineage III. D. vistulae Prost, 1957 and D. sphyrna Linstow, 1978 were used as the outgroup in the phylogenetic analyses based on the $18 \mathrm{~S}$ rDNA and ITS1 sequences.

All sequences of a given dataset were aligned using ClustalW multiple alignments [36] in Bioedit v. 7.2.5 [37]. The phylogenetic analyses were performed using unambiguous alignments. Gaps and ambiguously aligned regions were removed from alignments using GBlocks v. 0.91 [38]. The best-fit DNA evolution model was determined using the Akaike's information criterion (AIC) in JmodelTest 2.1.10 [39, 40]. Phylogenetic trees were inferred using minimum evolution (ME) analysis using PAUP* 4b10 [41], maximum likelihood (ML) analysis using PhyML 3.0 [42], and Bayesian inference (BI) analysis using MrBayes 3.2 [43]. Supports for internal nodes were computed from a bootstrap re-sampling procedure [44] with 1000 pseudoreplicates for $\mathrm{ME}$, and 500 pseudoreplicates for ML using the TBR algorithm. A search for the best ML tree was performed using the TBR branch-swapping algorithm. Bayesian inference (BI) analyses were performed using four Monte Carlo Markov chains running on 1000,000 generations for each data set, with trees being sampled every 100 generations. The "burn-in" asymptote was estimated by plotting the number of generations against the log likelihood scores for the saved trees, and all the trees (25\%) before stationarity were discarded as "burn-in". The posterior probabilities of the phylogeny and its branches were determined for all trees left in the plateau phase with the best ML scores.

The mapping of characters was performed in Mesquite 3.2 [45]. Prior to the mapping of characters, a new alignment was prepared using partial $28 \mathrm{~S}$ rDNA sequence data from 55 Dactylogyrus species. Phylogenetic reconstruction using BI analysis was performed as described above. Dactylogyrus bicornis Malewitzkaja, 1941 was used for rooting the phylogenetic tree following the output of phylogenetic analyses using the external outgroup. The first character mapped onto the phylogenetic reconstruction represents fish lineages, i.e. different fish families as applied in Yang et al. [16] (Acheilognathinae, Xenocyprinae, Gobioninae, Leuciscinae and Cyprininae as different character states). The second character represents fish lineages including the branching within Cyprininae, the target group of our study (Cyprinini,
Labeonini, Torini, Smiliogastrini, Barbini including the genus Barbus Cuvier \& Cloquet, 1816, and Barbini including the genus Luciobarbus were used as the character states). The revised classification of the subfamily Cyprininae by Yang et al. [16] was adopted for this mapping. The last character represents the distribution of host species with the following character states applied: southern Asia including Southeast Asia, a large part of Eurasia, Europe with only West Asia, the Iberian Peninsula, the Balkan Peninsula, Northwest Africa and West Africa. The distribution of cyprinid species follows Froese \& Pauly [46].

\section{Results}

An unambiguous alignment including the 55 Dactylogyrus species analysed and three outgroup species spanned 544 positions. The $T V M+I+G$ model was selected as the best-fit evolutionary model. The ME, ML and BI analyses provided phylogenetic trees with similar topologies. The BI tree is presented in Fig. 1, including bootstrap values resulting from ME and ML analyses and posterior probabilities resulting from BI analysis. The phylogenetic reconstructions revealed four Dactylogyrus lineages with D. bicornis in the basal position (Fig. 1). Dactylogyrus lineage I included two Dactylogyrus species parasitizing Asian Labeonini in the basal position, and the monophyletic group including 3 Dactylogyrus parasitizing Iberian Luciobarbus (the tribe Barbini within Cyprininae) and Dactylogyrus parasitizing Northwest African Carasobarbus fritschii (Günther, 1874) (the tribe Torini within Cyprininae) (Table 1, Fig. 1). The other three Dactylogyrus lineages (II, III and IV) formed a clade well supported by BI analysis but weakly supported by ME and unsupported by ML. Dactylogyrus lineage II included two groups of African Dactylogyrus. The first group included Dactylogyrus parasitizing small Enteromius Cope, 1867 species (Smiliogastrini) collected in West Africa (the basal position of this group was weakly supported by PP resulting from $\mathrm{BI}$ analysis and $\mathrm{BP}$ resulting from $\mathrm{ML}$ analysis and unsupported by BP resulting from ME analysis). The second group included Dactylogyrus species parasitizing West African Labeo Cuvier, 1816 (Labeonini) with the nested position of a single Dactylogyrus species ( $D$. marocanus El Gharbi, Birgi \& Lambert, 1994) from Northwest African cyprinins of the tribes Barbini and Torini. Dactylogyrus lineage II also included Dactylogyrus species parasitizing Cyprinus carpio Linnaeus, 1758 and the complex of Carassius auratus (Linnaeus, 1758), two species of Asian origin recently widely distributed in Europe. Dactylogyrus lineage III included the species collected from Europe and parasitizing Leuciscinae species, Barbus species (Barbini, Cyprininae) with a European distribution, and the Northwest African Luciobarus (Table 1). Phylogenetic relationships within Dactylogyrus lineage III 


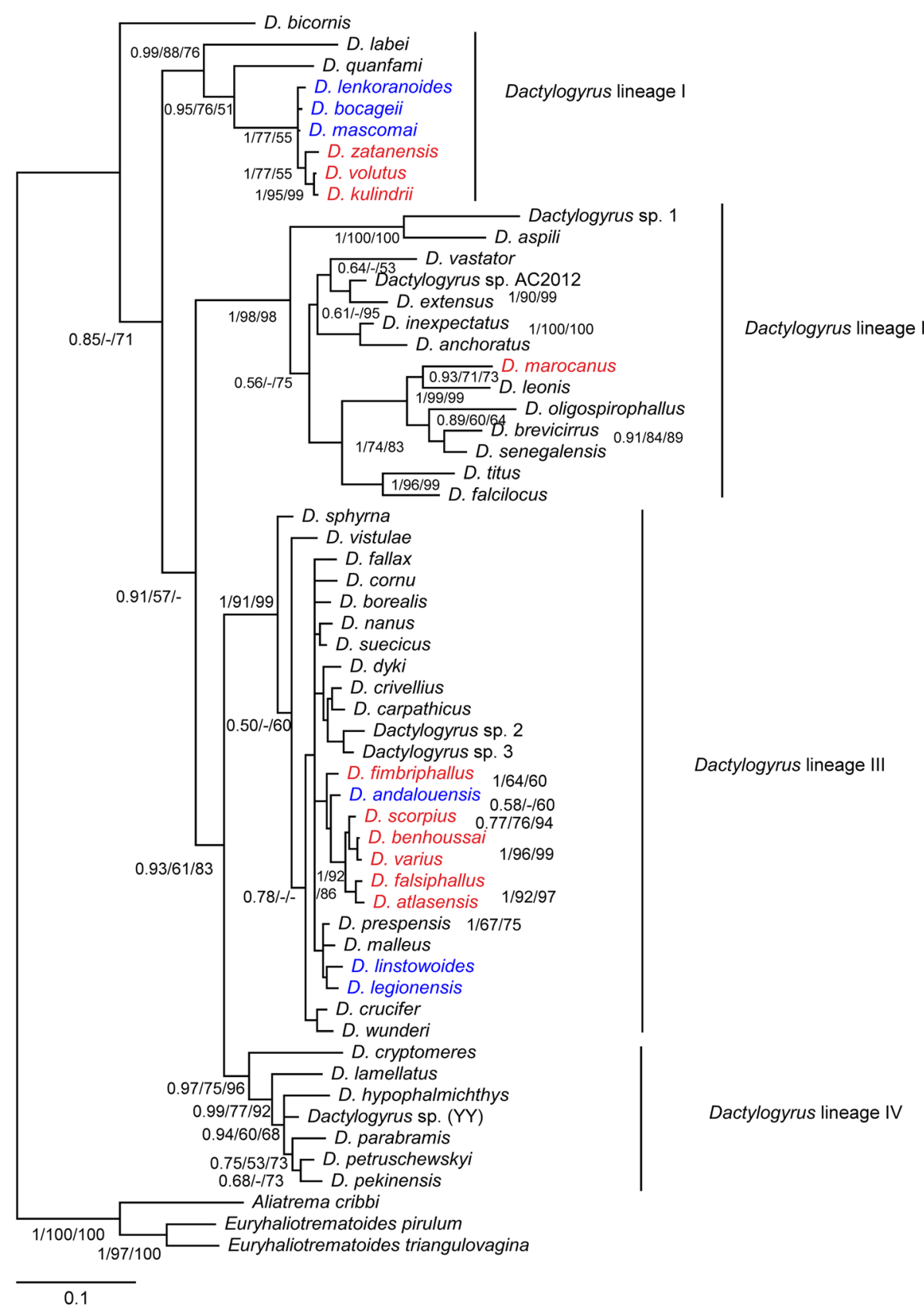

Fig. 1 Bayesian inference phylogenetic tree of Dactylogyrus species parasitizing different cyprinid lineages based on sequences of partial 285 rDNA. Dactylogyrus spp. from Northwest African cyprinids are shown in red. Dactylogyrus spp. from Iberian cyprinids are shown in blue. Values along branches indicate posterior probabilities and bootstrap values resulting from the following analyses: BI/ME/ML. Abbreviations: BI, Bayesian inference; ME, minimum evolution; ML, maximum likelihood. Aliatrema cribbi, Euryhaliotrematodes pirulum and E. triangulovagina were used as the outgroup

were either weakly resolved or unresolved by phylogenetic analyses. However, the monophyletic group including Dactylogyrus parasitizing Northwest African Luciobarbus species and D. andalousiensis El Gharbi, Renaud \& Lambert, 1992 parasitizing Iberian Luciobarbus sclateri Günther, 1868 was either well or moderately supported by our phylogenetic analyses. Dactylogyrus lineage IV included D. cryptomeres Bychowsky, 1943 parasitizing cyprinids of Gobioninae in the basal position and the well-supported monophyletic group of Dactylogyrus parasitizing Asian Xenocyprinae (Table 1, Fig. 1).

Because of the impossibility of reconstructing a reliable alignment when including Dactylogyrus species of highly diversified cyprinid lineages (i.e. because of the presence of many hypervariable regions and indels), we used only the representatives of Dactylogyrus lineage III 
in subsequent phylogenetic analyses to resolve the phylogenetic relationships within this lineage. An unambiguous alignment including Dactylogyrus species of lineage III spanned 1072 positions. The GTR + I + G model was selected as the best-fit evolutionary model. The ME, ML and BI analyses provided phylogenetic trees with similar topologies. The BI tree is presented in Fig. 2, including bootstrap values resulting from ME and ML analyses and posterior probabilities resulting from BI analysis. The basal position of $D$. andalousiensis in relation to the monophyletic group of Dactylogyrus species parasitizing Moroccan Luciobarbus was well supported by PP resulting from BI analysis and BP resulting from ME analysis, and moderately supported by BP resulted from ML analysis. Three Dactylogyrus species parasitizing Iberian Luciobarbus species formed a monophyletic group with two Dactylogyrus parasitizing Balkan Barbus species and one Dactylogyrus parasitizing Barbus species with a wide European distribution. This cluster was well supported by all phylogenetic analyses.
The mapping of characters was performed in the phylogenetic reconstruction (BI tree) of 55 Dactylogyrus species. An unambiguous alignment spanned 568 positions. The GTR $+\mathrm{I}+\mathrm{G}$ model was selected as the best evolutionary model. The mapping of the character of cyprinid lineages (i.e. cyprinid subfamilies) onto the phylogenetic reconstruction (Fig. 3) showed that Acheilognathinae is the most plesiomorphic host group for Dactylogyrus. Dactylogyrus of the Cyprininae are included in three lineages. The Gobioninae, Xenocyprinae and Leuciscinae were likely colonized by Dactylogyrus from the Cyprininae. However, some Cyprininae were secondarily colonized by Dactylogyrus from the Leuciscinae. The mapping of the cyprinid distribution onto the phylogenetic reconstruction (Fig. 4) showed the Asian origin of Dactylogyrus. This mapping revealed (i) the multiple origins of Northwest African Dactylogyrus, and (ii) the phylogenetic relatedness between Dactylogyrus parasitizing the Cyprininae of Labeonini, Cyprinini, Torini and some of Barbini across different continents. Northwest

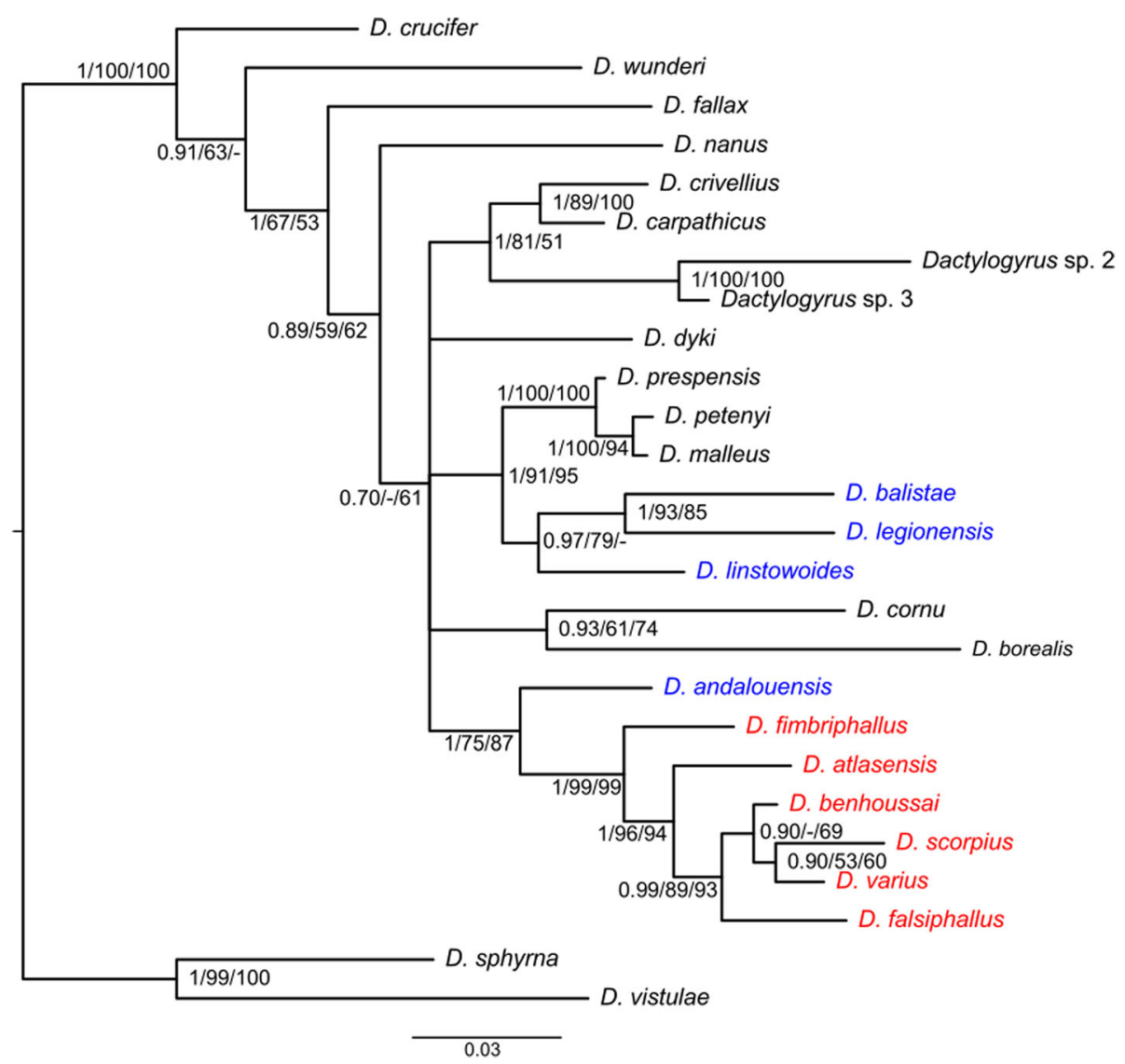

Fig. 2 Phylogenetic tree of Dactylogyrus species belonging to Dactylogyrus lineage III constructed by Bayesian inference analysis. The tree is based on sequences of partial 185 rDNA and ITS1. Dactylogyrus spp. from Northwest African cyprinids are shown in red. Dactylogyrus spp. from Iberian cyprinids are shown in blue. Values along branches indicate posterior probabilities and bootstrap values resulting from the following analyses: BI/ME/ML. Abbreviations: BI, Bayesian inference; ME, minimum evolution; ML, maximum likelihood 


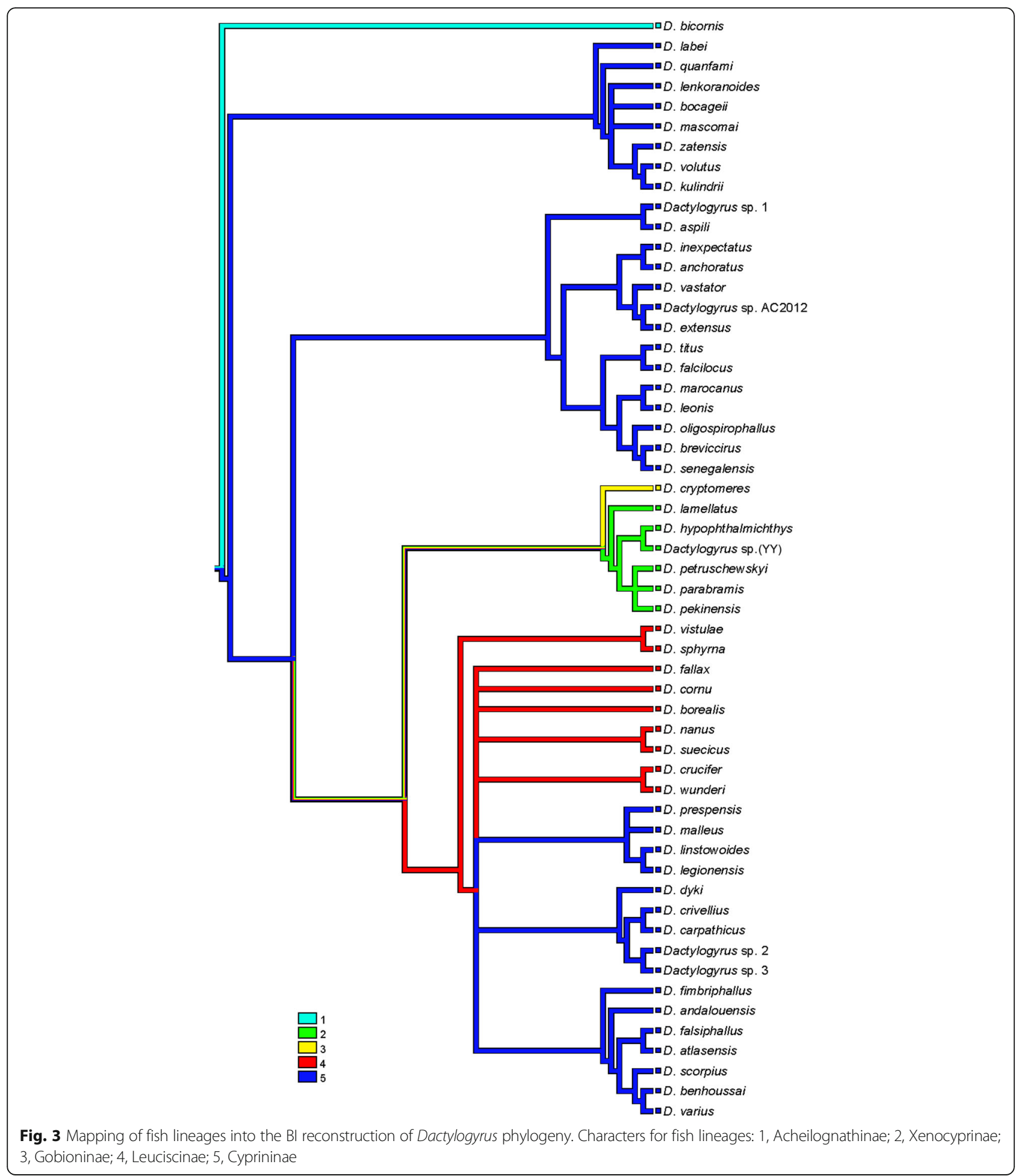

African Dactylogyrus parasitizing Carasobarbus fritschii (the tribe Torini within Cyprininae, see Fig. 5) are phylogenetically closely related to Asian Dactylogyrus species. Dactylogyrus marocanus is of African origin. Our mapping suggests that $D$. marocanus diverged within Dactylogyrus of African Labeonini and switched to Moroccan cyprinids (a morphologically and genetically identical form of this parasite was found in two species of Torini and two Luciobarbus species of Barbini). Dactylogyrus parasitizing Northwest African Luciobarbus are of European origin (Fig. 4). In addition, our analyses also showed the multiple origins of Dactylogyrus parasitizing Iberian Luciobarbus. 


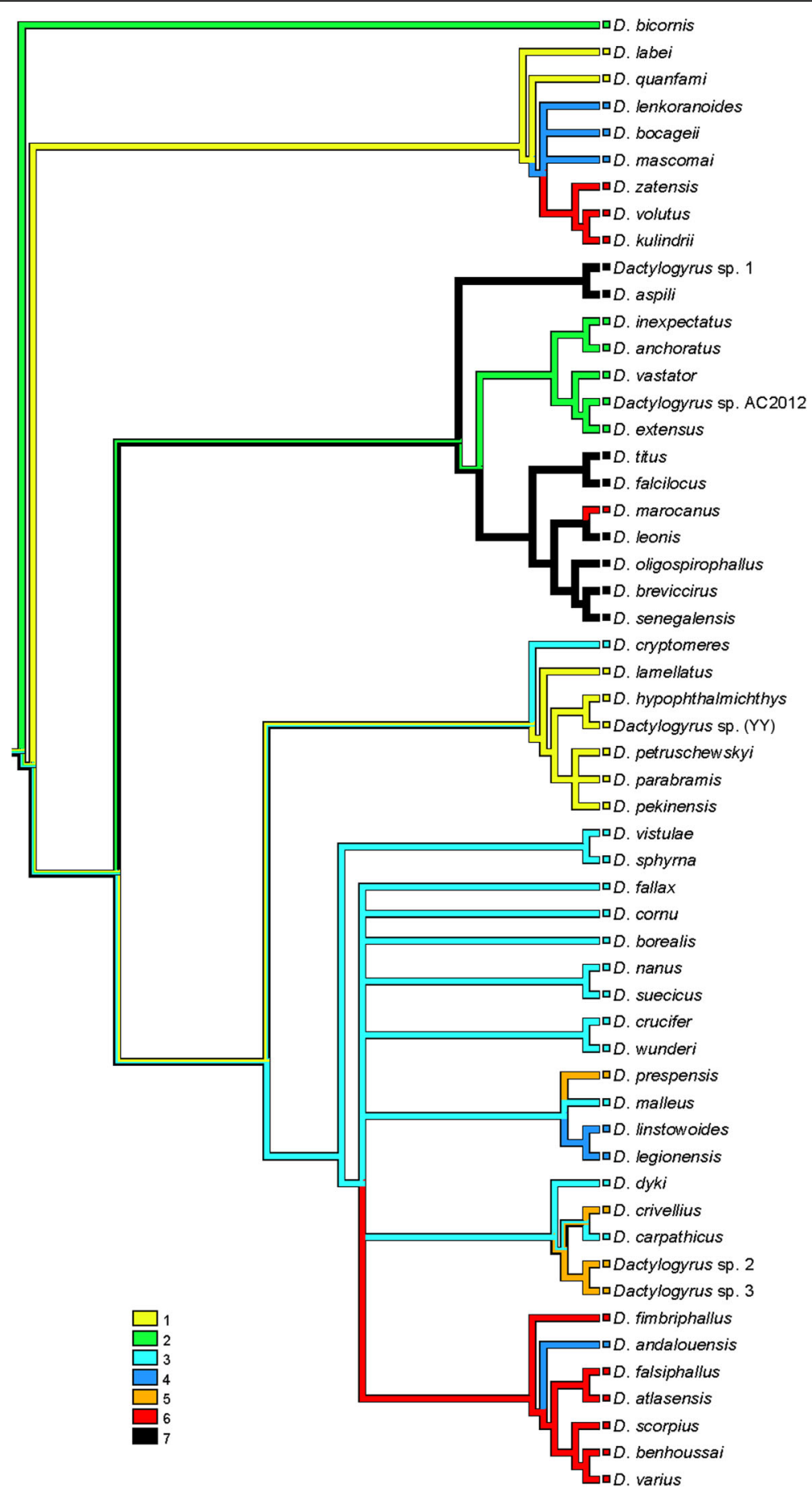

Fig. 4 Mapping of fish distribution onto the BI reconstruction of Dactylogyrus phylogeny. Characters for fish distribution: 1, South and Southeast Asia; 2, Eurasia; 3, Europe with West Asia; 4, Iberian Peninsula; 5, Balkan Peninsula; 6, Northwest Africa (Mediterranean Africa); 7, West Africa. Note: The area of introduction was not considered when fish distribution was evaluated. Concerning C. gibelio, it is not clear whether this species is native or introduced into Europe; therefore, we retained Eurasia

The mapping of fish distribution onto Dactylogyrus phylogeny demonstrated that one group of Dactylogyrus parasitizing Iberian Luciobarbus (i.e. D. mascomai El Gharbi, Renaud \& Lambert, 1992, D. lenkoranoides El Gharbi,
Renaud \& Lambert, 1992 and D. bocageii Alvarez Pellitero, Simón Vicente \& González Lanza, 1981) and the group of Dactylogyrus parasitizing Northwest African Torini probably originated from Asian cyprinids (most likely 


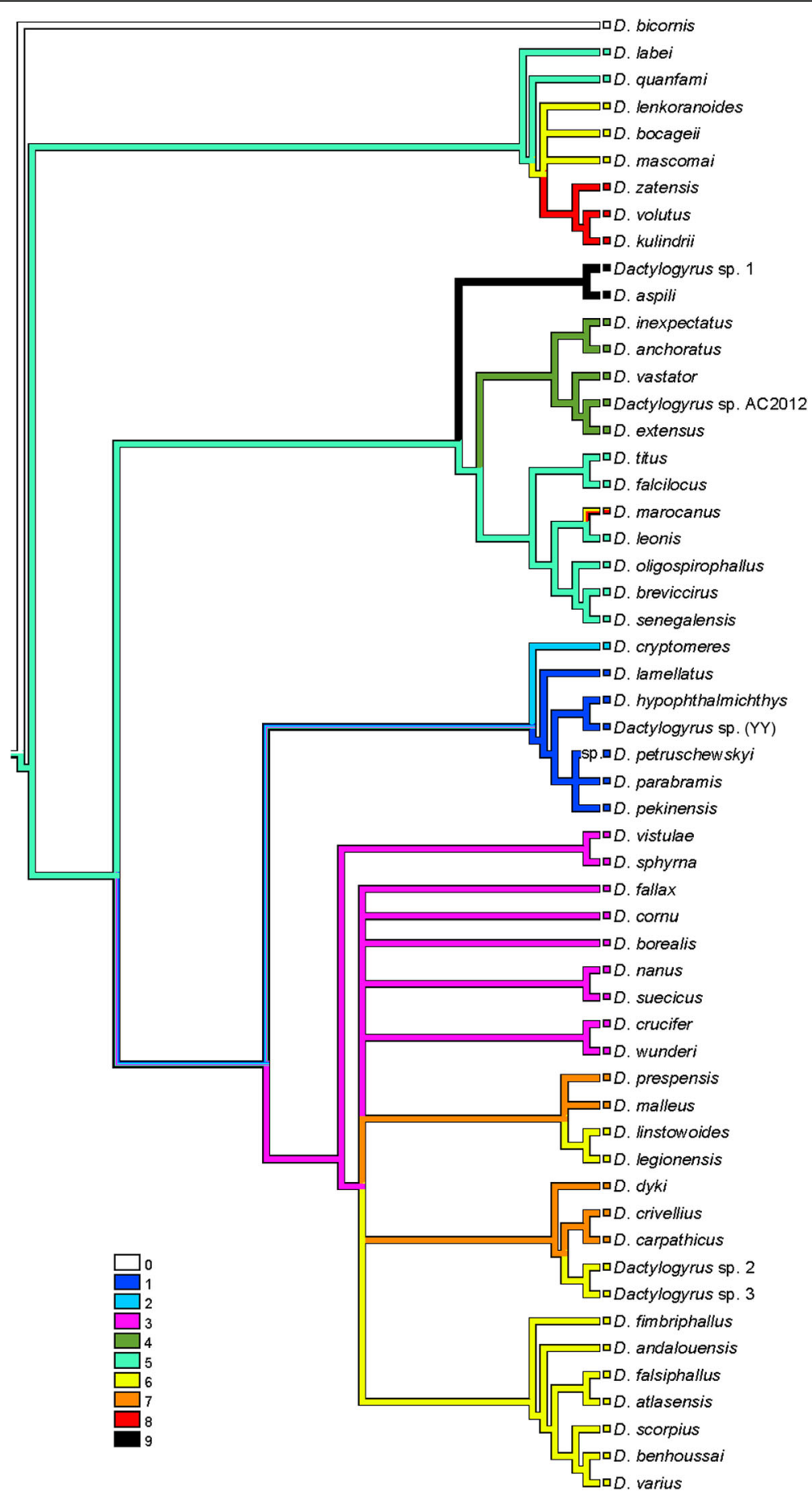

Fig. 5 Mapping of fish lineages including detailed branching of Cyprininae into the BI reconstruction of Dactylogyrus phylogeny. Characters for fish lineages: 0, Acheilognathinae; 1, Xenocyprinae; 2, Gobioninae; 3, Leuciscinae; 4, Cyprininae - Cyprinini; 5, Cyprininae - Labeonini; 6, Cyprininae - Barbini - Luciobarbus; 7, Cyprininae - Barbini - Barbus; 8, Cyprininae - Torini; 9, Cyprininae - Smiliogastrini

Labeonini). However, the other three Dactylogyrus of Iberian Luciobarbus are most probably of European origin. Whilst D. linstowoides El Gharbi, Renaud \& Lambert, 1992 and D. legionensis González Lanza \& Alvarez Pellitero, 1982 form the monophyletic group with the European
Dactylogyrus of Barbus species, D. andalousiensis is included in the monophyletic group of Northwest African Luciobarbus species within Dactylogyrus of lineage III (i.e. the lineage including Dactylogyrus of Leuciscinae and some Dactylogyrus species of Barbus-Luciobarbus group). 


\section{Discussion}

The present study was focused on host-specific monogeneans of Dactylogyrus as a potential tool for inferring historical contacts among their cyprinid hosts in the Mediterranean region, which is characterized by a high degree of endemism among cyprinid species. As indicated by a previous study $[11,12]$ and confirmed by our study, endemic Mediterranean cyprinids harbour endemic Dactylogyrus fauna. We investigated the origin of host-specific Dactylogyrus parasitizing Northwest African and Iberian cyprinid hosts, hypothesizing that phylogenetic relationships between Dactylogyrus species may cast new light on the biogeographical history of this fish group.

Šimková et al. [10] reconstructed the phylogeny of Dactylogyrus parasitizing central European cyprinid species (also including some invasive or introduced species). They presented evidence for three Dactylogyrus lineages in central Europe: the first includes Dactylogyrus of the Cyprininae (tribe Cyprinini), originating from Southeast Asia and historically introduced into Europe; the second includes Dactylogyrus of the Rasborinae and Xenocyprininae (the fish species of both groups originating from Southeast Asia and introduced into Europe) and the Gobioninae; and the last, a very diversified lineage, includes Dactylogyrus of the Leuciscinae and European Barbus (Barbini within Cyprininae). Šimková et al. [10] showed that the phylogenetic relationships between Dactylogyrus linages reflected the phylogenetic relationships between cyprinid lineages (recently represented by cyprinid subfamilies), except for the particular position of Dactylogyrus species parasitizing European Barbus species, which were nested within the highly diversified clade of Dactylogyrus parasitizing European Leuciscinae.

Herein, the phylogenetic position of Dactylogyrus parasitizing African cyprinids was evaluated for the first time. By our phylogenetic analyses, we showed that Dactylogyrus parasitizing the African cyprinids investigated in our study belong to three different lineages (I, II and III), which suggests their different origins and presumably also reflects the different histories of their cyprinid hosts. Dactylogyrus lineage II includes Dactylogyrus parasitizing the Cyprinini of Southeast Asian origin and West African Cyprininae (Labeonini investigated in our study), which suggests that West African cyprinids and their co-evolving Dactylogyrus originated from Asia (the basal position of D. aspili and Dactylogyrus sp. from small African Enteromius was not supported). This is in accordance with predictions on the origin of African cyprinid fauna [16, 25].

However, the situation concerning the origin of Northwest African cyprinids and their Dactylogyrus parasites is more complicated. Dactylogyrus marocanus, a single species infecting both Northwest African tribes of the Cyprininae, Torini and Barbini, was nested within
Dactylogyrus lineage II. This parasite occurring on the representatives of two cyprinine lineages was previously reported in seven cyprinin species, mostly the representatives of Torini, by El Gharbi et al. [12] and also documented by our study. We showed a morphologically and genetically identical form of this species in Carasobarbus fritschii, Pterocapoeta maroccana Günther, 1902, Luciobarbus ksibii Boulanger, 1905 and L. zayanensis Doadrio, Casal-Lopéz \& Yahyaoui, 2016. However, the abundance of $D$. marocanus was higher in two Torini species than in Luciobarbus species, suggesting that Torini are the main host species for its reproduction (see [9]). Dactylogyrus marocanus clusters within West African Dactylogyrus species parasitizing Labeo species, suggesting a single host-switch by Dactylogyrus to Northwest African Cyprininae from the group of Cyprininae achieving high diversification on the African continent. The attachment organ (haptor) of $D$. marocanus is of the same morphological type as that recognized for Dactylogyrus of West African Labeo, Dactylogyrus of small West African Enteromius, and two Dactylogyrus of Cyprinini of Southeast Asian origin i.e. D. inexpectatus Isjumova in Gussev, 1955 and D. anchoratus (Dujardin, 1845). In addition, D. marocanus is the only species with this type of haptor within the Dactylogyrus species parasitizing Northwest African cyprinids. This may suggest that haptor morphology, in this case, is a character shared by common ancestry. The similar morphology of the haptor in Dactylogyrus parasitizing phylogenetically closely related cyprinid species was previously demonstrated by Šimková et al. [9].

Our phylogenetic analyses using cyprinid-specific Dactylogyrus spp. confirmed the occurrence of different independent dispersal events from Asia (or Eurasia) to Africa concerning the Moroccan cyprinids belonging to hexaploid Torini (Carasobarbus fritschii and Pterocapoeta maroccana in our study) and tetraploid Barbini (Luciobarbus species), as was highlighted by the molecular phylogeny of cyprinid species [16, 17]. Middle East Carasobarbus and Northwest African Carasobarbus form a monophyletic group within the Labeobarbus clade, and Pterocapoeta occupies the basal position in this clade $[16,17]$. Wang et al. [47] proposed that the group comprising the Carasobarbus lineage originated about 9.94 MYA in the Orient. The Carasobarbus lineage separated about 7.7 MYA. Tsigenopoulos et al. [17] dated the beginning of the diversification of the African hexaploid lineage to the Late Miocene following the closing of the seaway between the Mediterranean Sea and the Indian Ocean and the emergence of the Gomphotherium land bridge between Africa and Asia (the Arabian tectonic Plate) in the Middle Miocene. In the Tortonian stage, the Anatolian tectonic Plate (Asia Minor) was connected to the Arabian Plate to the east and was separated from Europe to the west, where 
the Aegean Sea formed [48]; this explains the absence of Torini in Europe [17]. The phylogenetic position of Dactylogyrus parasitizing Carasobarbus fritschii within Dactylogyrus lineage I and the phylogenetic affinity between Dactylogyrus species parasitizing South Asian Labeonini and Dactylogyrus species parasitizing Northwest African cyprinid species is in line with the hypothesis of the origin and historical dispersion of Northwest African Torini. The molecular phylogeny of tribes belonging to Cyprininae showed Labeonini to be a sister group to the group including other tribes with Torini in the basal position [16]. This may suggest close phylogenetic relationships between Dactylogyrus of Torini and Labeonini. However, our study suggests the need for future phylogenetic studies to investigate also the position of Dactylogyrus of Asian and African representatives of Torini as well as Dactylogyrus parasitizing other cyprinin tribes to specify the origin of Dactylogyrus diversity in Northwest African Torini.

Concerning the Mediterranean diversity of cyprinids, there are three main hypotheses of their historical dispersion explaining their actual distribution. All suggest that the cyprinids originated in Asia and reached the Mediterranean peninsulas via three main routes, a northern route [21], a southern route via land bridges connecting continents [25], and dispersion through the Mediterranean Sea during its supposed freshwater phase at the end of the Messinian [24]. According to the northern dispersal scenario, cyprinids dispersed slowly via river captures, through Siberia, and then from northern into southern Europe, from the late Oligocene until the late Pliocene (35-1.7 MYA). The colonization of southern Europe occurred before the alpine orogeny during the Miocene, which separated freshwater connections between northern and southern Europe [49]. Concerning Luciobarbus, it is hypothesized that they spread through central Europe to the Iberian Peninsula and Northwest Africa, and that, afterwards, a second invasion of Barbus from Asia colonized central Europe, where Barbus replaced Luciobarbus (except in the Iberian Peninsula due to the ancient isolation of the Iberian Peninsula from the rest of the European continent). This hypothesis was rejected for Iberian Luciobarbus by Zardoya \& Doadrio [18]. According to the southern route hypothesis, cyprinids dispersed from Asia through Asia Minor via land bridges (Asian-AnatolianIranian, 33 MYA, and the Gomphotherium land bridge, 19 MYA) to the Balkans and Northern Africa, and subsequently to the Iberian Peninsula [24]. In accordance with this scenario, it is supposed that Luciobarbus colonized the Iberian Peninsula from Africa via southern Spain [18, 23]. The Lago Mare dispersal scenario [24] assumes that after the Messinian salinity crisis (5 MYA) the Mediterranean Sea underwent a lacustrine phase allowing the dispersion of freshwater fishes. This scenario predicts higher phylogenetic affinity among species in Mediterranean areas. Although this hypothesis is still widely cited, it has been largely discredited, both by geological evidence and phylogenetic studies (e.g. $[19,25])$.

Recent views on the historical dispersion of Luciobarbus are, however, ambiguous. On the basis of morphological characters, Iberian and North African barbels are closely related to central European species, supporting the northern route of dispersion [21, 22], whilst molecular phylogenetic studies and a lack of fossil records of Luciobarbus in central Europe support the southern route of Iberian Luciobarbus dispersion [18, 19, 26]. Our phylogenetic reconstruction using host-specific Dactylogyrus would suggest that the northern route represents the more plausible scenario explaining the historical dispersion of Luciobarbus in Northwest Africa. This scenario is supported by our phylogenetic analyses, which indicate that (i) Dactylogyrus species parasitizing Northwest African Luciobarbus have a clearly European origin, and (ii) the monophyletic group of Dactylogyrus including $D$. balistae Simón Vicente, 1981, D. legionensis and D. linstowoides parasitizing Iberian Luciobarbus form a wellsupported clade with Dactylogyrus parasitizing European Barbus. In addition, the Iberian species $D$. andalousiensis occupies the basal position in the clade including the monophyletic group of Dactylogyrus species parasitizing Northwest African Luciobarbus (a finding well supported by BP and PP using the combined data of partial $18 \mathrm{~S}$ rDNA and ITS1). Even though our sampling of Dactylogyrus parasites did not include Dactylogyrus representatives of Middle East cyprinids, we showed that Dactylogyrus species parasitizing Northwest African Luciobarbus, four of the Dactylogyrus species parasitizing Iberian Luciobarbus, Dactylogyrus species parasitizing Greek Luciobarbus, Dactylogyrus species parasitizing Balkan Barbus, and Dactylogyrus species parasitizing the widely distributed European Barbus barbus form together with Dactylogyrus parasitizing Leuciscinae the wellsupported lineage III. This may suggest the common origin of Dactylogyrus parasitizing Luciobarbus/Barbus (Cyprininae) of different Mediterranean areas and Dactylogyrus of European Leuciscinae. Indubitably, there is a strong relationship between Dactylogyrus parasitizing Northwest African Luciobarbus (Barbini) and those parasitizing European cyprinids belonging to the subfamily Leuciscinae and the tribe Barbini of the subfamily Cyprininae, identified in our Dactylogyrus lineage III. However, in this case, there is a large discrepancy between the phylogenies of the hosts and Dactylogyrus parasites, and the relationships in lineage III rather point to historical host-switching events.

In our study, we showed the close phylogenetic relationships between (i) Dactylogyrus parasitizing Northwest African Torini and one group of Dactylogyrus 
parasitizing Iberian Luciobarbus species and (ii) Dactylogyrus parasitizing Northwest African Barbini and the second group of Dactylogyrus parasitizing also Iberian Luciobarbus species. This revealed (i) multiple historical contacts between Iberian Luciobarbus and two different lineages of Northwest African cyprinids with different origins and historical dispersions, and subsequently (ii) two independent diversifications of Dactylogyrus in Iberian Luciobarbus. The exchange of fauna between the Iberian Peninsula and Northwest Africa is hypothesized for the beginning of the Messinian salinity crisis 5.96 MYA [50], which was initiated by the closing of the Betic and Rifian corridors in Spain and Morocco [51-53]. If this event was responsible for the common origin of Dactylogyrus parasitizing Iberian and Northwest African cyprinids, the origin and diversification of Iberian Luciobarbus seem to be older than predicted by the Lago Mare route of Luciobarbus dispersion. Mesquita et al. [54] suggested an even earlier differentiation of Mediterranean Luciobarbus lineages (7.3 MYA). At the end of the Messinian 5.33 MYA, all connections between North African and Iberian populations were closed by the formation of the Strait of Gibraltar [52]. However, Machordom \& Doadrio [19] suggested that the Betic area was connected with the Kabilian Mountains after its isolation from the Rifian area by the Betic-Kabilian plate in the Pliocene (3.3 MYA). Cahuzac et al. [55] proposed the existence of plates also between southern Spain and the Maghreb. These plates may potentially have served as the contact zones between Iberian and North African cyprinids and may alternatively have contributed to the common ancestry of Dactylogyrus parasitizing Iberian Luciobarbus and Northwest African Torini or Barbini. However, we failed to identify any reliable resource documenting historical contacts between Iberian Luciobarbus and the two Moroccan cyprinid lineages.

Mesquita et al. [54] identified three polytomic evolutionary lineages of Iberian Luciobarbus, potentially suggesting multiple speciation events which could likely explain the evidence of two lineages for Iberian Dactylogyrus. However, the different positions of the two Iberian Dactylogyrus lineages in the phylogenetic tree have no association with the evolution and recent distribution of Iberian Luciobarbus (according to [54]), L. bocagei (Steindachner, 1864) representing the Atlantic lineage, L. guiraonis (Steindachner, 1866) representing the Mediterranean lineage, and L. sclateri representing the South-Western and South-Eastern lineage. Dactylogyrus bocageii, previously reported as a species endemic to Spanish Luciobarbus [11], was present in all three Iberian Luciobarbus species investigated in our study and living recently in allopatry. As indicated before, $D$. andalousiensis is a single Iberian Dactylogyrus species with the basal position in the clade including the monophyletic group of Dactylogyrus species parasitizing the Northwest African Luciobarbus. This parasite was previously recorded on two Luciobarbus species, namely L. sclateri and L. microcephalus (Almaça, 1967), both restricted to southern Portugal and Spain [11], but representing different evolutionary lineages [54].

\section{Conclusions}

To our knowledge, this study is the first to investigate the origin and phylogenetic position of Northwest African and Iberian Dactylogyrus, monogenean parasites specific to cyprinid fish. The phylogenetic reconstruction of these host-specific monogeneans sheds new light on historical contacts between African and European (here Iberian) cyprinids, these contacts associated with host switches of Dactylogyrus parasites. More specifically, phylogenetic analyses using Dactylogyrus demonstrated different and independent dispersal events from Asia (or Eurasia) to Africa concerning two lineages of Moroccan cyprinids: (i) Carasobarbus fritschii and Pterocapoeta maroccana belonging to hexaploid Torini, and (ii) Luciobarbus species belonging to teptraploid Barbini. In addition, our study revealed that Dactylogyrus parasitizing Iberian Luciobarbus do not form a monophyletic group, i.e. we demonstrated close phylogenetic relationships between (i) Dactylogyrus parasitizing Northwest African Torini and one group of Dactylogyrus parasitizing Iberian Luciobarbus species, and (ii) Dactylogyrus parasitizing Northwest African Barbini and the second group of Dactylogyrus parasitizing also Iberian Luciobarbus. This suggests multiple historical contacts between Iberian Luciobarbus and Northwest African cyprinids with different origins and historical dispersions, and subsequently two independent diversification of Dactylogyrus in Iberian Luciobarbus.

\section{Acknowledgements}

We are grateful to Mária Lujza Kičinjaová, Eva Řehulková, Tomáš Pakosta, and Jaroslav Červenka for their help with the fish examination, parasite collection and fixation. We thank Radek Šanda (National Museum, Czech Republic) for help with fish sampling. We also thank Carla Sousa-Santos (ISPA Instituto Universitário,

Portugal), colleagues from Piscifactoría de El Palmar (Spain), Stamatis Zogaris (Hellenic Centre for Marine Research, Greece), Dejan Radoševic (Republic Institute for Protection of Cultural, Historical and Natural Heritage, Bosnia and Herzegovina), Antoine Pariselle (IRD, France), and Ouafae Berrada Rkhami (Mohammed V

University in Rabat, Morocco) for arranging permits and assisting with fieldwork. We kindly thank Matthew Nicholls for English revision of the final draft.

\section{Funding}

This study was funded by the Czech Science Foundation (grant No. 15-19382S).

\section{Availability of data and materials}

The data supporting the conclusions of this study are included in this article. The newly generated sequences were submitted to the GenBank database under the accession numbers shown in Table 1.

Authors' contributions

$A \breve{S}$ conceived the ideas and designed the study. AŠ, MB, IR and JV conducted the fieldwork and collected the data. AŠ, MB and IR analysed the data. AŠ wrote 
the manuscript with assistance from JV. All authors read and approved the final manuscript.

\section{Ethics approval}

All applicable institutional, national, and international guidelines for the care and use of animals were followed. This study was approved by the Animal Care and Use Committee of the Faculty of Science, Masaryk University in Brno (Czech Republic)

\section{Consent for publication}

Not applicable.

\section{Competing interests}

The authors declare that they have no competing interests.

\section{Publisher's Note}

Springer Nature remains neutral with regard to jurisdictional claims in published maps and institutional affiliations.

\section{Author details}

'Department of Botany and Zoology, Faculty of Science, Masaryk University, Kotlářská 2, 61137 Brno, Czech Republic. 'Laboratory of Biodiversity, Ecology and Genome, Faculty of Sciences, Mohammed V University in Rabat, Ibn Batouta 4, 1014 RP Rabat, Morocco. ${ }^{3}$ Department of Ecology, Faculty of Science, Charles University, Viničná 7, 12844 Prague 2, Czech Republic.

Received: 3 July 2017 Accepted: 5 November 2017

Published online: 28 November 2017

\section{References}

1. Ronquist F. Phylogenetic approaches in coevolution and biogeography. Zool Scr. 1997;26:313-22

2. Brooks DR, McLennan DA. Parascript: parasites and the language of evolution. Washington, DC: Smithsonian Institution Press; 1993.

3. Hoberg EP, Klassen GJ. Revealing the faunal tapestry: coevolution and historical biogeography of hosts and parasites in marine systems. Parasitology. 2002;124:3-22.

4. Poulin R. Evolutionary ecology of parasites: from individuals to communities London: Chapmann \& Hall; 1998.

5. Rohde K. Ecology and biogeography of marine parasites. Adv Mar Biol. 2002:43:1-86.

6. Pérez-Ponce de León G, Choudhury A. Biogeography of helminth parasites of freshwater fishes in Mexico: the search for patterns and processes. J Biogeogr. 2005;32:645-59.

7. Choudhury A, Dick TA. Sturgeons (Chondrostei: Acipenseridae) and their metazoan parasites: patterns and processes in historical biogeography. Biogeogr. 2001;28:1411-39.

8. McDowell RM. Biogeography of the southern cool-temperate galaxioid fishes: evidence from metazoan macroparasite faunas. J Biogeogr. 2000; 27:1221-9.

9. Šimková A, Verneau O, Gelnar M, Morand S. Specificity and specialization of congeneric monogeneans parasitizing cyprinid fish. Evolution. 2006:60:1023-37.

10. Šimková A, Morand S, Jobet E, Gelnar M, Verneau O. Molecular phylogeny of congeneric monogenean parasites (Dactylogyrus): a case of intrahost speciation. Evolution. 2004;58:1001-18.

11. El Gharbi S, Renaud F, Lambert A. Dactylogyrids (Platyhelminthes: Monogenea) of Barbus spp. (Teleostei: Cyprinidae) from the Iberian peninsula. Res Rev Parasitol. 1992;52:103-16.

12. El Gharbi S, Birgi E, Lambert A. Monogènes Dactylogyridae parasites de Cyprinidae du genre Barbus d'Afrique du Nord. Syst Parasitol. 1994;27:45-70.

13. Dupont F. Biogeographie historique des Dactylogyrus, monogènes parasites de poissons Cyprinidae dans la peninsula Balkanique. Biol Gallo-Hellenica. 1989;13:145-52.

14. Dupont $F$, Lambert $A$. Étude de communautés de monogènes Dactylogyridae parasites des Cyprinidae du Lac Mikri Prespa (Nord de la Grèce). Description de trois nouvelles espèces chez un Barbus endémique: Barbus cyclolepis prespensis Karaman, 1924. Ann Parasitol Hum Comp. 1986; 61:597-616

15. Winfield IJ, Nelson JS. Cyprinid fishes. Systematics, biology and exploitation. London: Chapman and Hall, Fish and Fisheries Series 3; 1991.
16. Yang L, Sado T, Hirt MV, Pasco-Viel E, Arunachalam M, Li J, et al. Phylogeny and polyploidy: resolving the classification of cyprinid fishes (Teleostei: Cypriniformes). Mol Phylogenet Evol 2015;85:97-116.

17. Tsigenopoulos CS, Kasapidis P, Berrebi P. Phylogenetic relationships of hexaploid large-sized barbs (genus Labeobarbus, Cyprinidae) based on mtDNA data. Mol Phylogenet Evol. 2010:56:851-6.

18. Zardoya R, Doadrio I. Phylogenetic relationships of Iberian cyprinids: systematic and biogeographical implications. Proc R Soc Lond B. 1998; 265:1365-72.

19. Machordom A, Doadrio I. Evidence of the Cenozoic Betic-Kabilian connection based on freshwater fish phylogeny (Luciobarbus, Cyprinidae). Mol Phylogenet Evol 2001;18:252-63.

20. Doadrio I, Casal-López M, Perea S, Yahyaoui A. Taxonomy of rheophilic Luciobarbus Heckel, 1842 (Actinopterygii, Cyprinidae) from Morocco with the description of two new species. Graellsia. 2016:72:e039.

21. Banarescu P. Some reconsiderations of the zoogeography of the euro-Mediterranean fresh-water fish fauna. Rev Romane Biol Zool. 1973;18:257-64.

22. Almaça C. Remarks on the biogeography of the euro-Mediterranean Barbus (Cyprinidae, Pisces). Bull Ecol. 1988;19:159-62.

23. Doadrio I. Phylogenetic relationships and classification of western Palearctic species of the genus Barbus (Osteichthyes, Cyprinidae). Aquat Living Resour 1990;3:265-82.

24. Bianco PG. Potential role of the paleohistory of the Mediterranean and Paratethys basins on the early dispersal of Mediterranean freshwater fishes. Ichthyol Explor Fres. 1990;1:167-84.

25. Perea S, Böhme M, Zupančic P, Freyhof J, Šanda R, Özulug M, et al. Phylogenetic relationships and biogeographical patterns in circumMediterranean subfamily Leuciscinae (Teleostei, Cyprinidae) inferred from both mitochondrial and nuclear data. BMC Evol Biol. 2010:10:265.

26. Tsigenopoulos CS, Durand JD, Unlu E, Berrebi P. Rapid radiation of the Mediterranean Luciobarbus species (Cyprinidae) after the Messinian salinity crisis of the Mediterranean Sea, inferred from mitochondrial phylogenetic analysis. Biol J Linn Soc. 2003:80:207-22.

27. Ergens R, Lom J. Causative agents of fish diseases. Prague: Academia; 1970. (in Czech)

28. Paperna I. Monogenean of inland water fish in Africa. Annal Mus R Aft C SC Zool. 1979:226:1-131.

29. Gusev AV. [Metazoan parasites. Part I.] In: Bauer ON, editor. Identification key to parasites of freshwater fish. Vol. 2. Leningrad: Nauka; 1985 (In Russian).

30. Birgi E, Lambert A. Les Dactylogyridae (Platyhelminthes, Monogenea) des Cyprinidae du genre Barbus du Sud Cameroun. Rev Hydrobiol Trop. 1987; 20:37-48.

31. Musilová N, Řehulková E, Gelnar M. Dactylogyrids (Platyhelminthes: Monogenea) from the gills of the African carps, Labeo coubie Rüppell (Cyprinidae), from Senegal, with the descriptions of three new species of Dactylogyrus and the redescription of Dactylogyrus cyclocirrus Paperna, 1973. Zootaxa. 2009;2241:47-68.

32. Rahmouni I, Řehulková E, Pariselle A, Berrada Rkhami O, Šimková A. Four new species of Dactylogyrus (Monogenea: Dactylogyridae) parasitizing the gills of northern Moroccan Luciobarbus (Cyprinidae): morphological and molecular characterization. Syst Parasitol. 2017;94:575-91.

33. Hassouna N, Michot B, Bachellerie JP. The complete nucleotide sequence of mouse 285 rRNA gene. Implications for the process of size increase of the large subunit rRNA in higher eukaryotes. Nucl Acids Res. 1984;12:3563-83.

34. Šimková A, Matějusová I, Cunningham CO. A molecular phylogeny of the Dactylogyridae sensu Kritsky \& Boeger (1989) (Monogenea) based on the D1-D3 domains of large subunit rDNA. Parasitology. 2006;132:43-53.

35. Šimková A, Plaisance L, Matějusová I, Morand S, Verneau O. Phylogenetic relationships of the Dactylogyridae Bychowski, 1933 (Monogenea: Dactylogyridea): the need for the systematic revision of the Ancyrocephalinae Bychowsky, 1937. Syst Parasitol. 2003:54:1-11.

36. Thompson JD, Higgins DG, Gibson TJ. CLUSTAL W: improving the sensitivity of progressive multiple sequence alignment through sequence weighting position-specific gap penalties and weight matrix choice. Nucl Acids Res. 1994:22:4673-80.

37. Hall TA. BioEdit: a user-friendly biological sequence alignment editor and analysis program for windows 95/98/NT. Nucl Acids Symp Ser. 1999:41:95-8.

38. Talavera G, Castresana J. Improvement of phylogenies after removing divergent and ambiguously aligned blocks from protein sequence alignments. Syst Biol. 2007;56:564-77. 
39. Guindon S, Gascuel O. A simple, fast and accurate algorithm to estimate large phylogenies by maximum likelihood. Syst Biol. 2003;27:1759-67.

40. Darriba D, Taboala GL, Doallo R, Posada D. JModelTest2: more models, new heuristics and parallel computing. Nat Methods. 2012;9:772

41. Swofford DL. PAUP* Phylogenetic analysis using parsimony (*and other methods). Version 4.0b10. Sunderland: Sinauer Associates; 2002.

42. Guindon S, Dufayard JF, Lefort V, Anisimova M, Hordijk W, Gascuel O. New algorithms and methods to estimate maximum-likelihood phylogenies: assessing the performance of PhyML 3.0. Syst Biol. 2010;59:307-21.

43. Ronquist F, Teslenko M, van der Mark P, Ayres DL, Darling A, Hohna S, et al. MrBayes 3.2: efficient Bayesian phylogenetic inference and model choice across a large model space. Syst Biol. 2012;61:539-42.

44. Felsenstein J. Confidence limits on phylogenies: an approach using the bootstrap. Evolution. 1985;39:783-91.

45. Maddison WP, Maddison DR. Mesquite: a modular system for evolutionary analysis. Version. 2017;3:2. http://mesquiteproject.org

46. Froese R, Pauly D. FishBase. World Wide Web electronic publication. www. fishbase.org, Accessed 12 Feb 2017.

47. Wang J, Wu XY, Chen ZM, Yue ZP, Ma W, Chen SZ, et al. Molecular phylogeny of European and African Barbus and their west Asian relatives in the Cyprininae (Teleostei: Cypriniformes) and orogenesis of the QinghaiTibetan plateau. Chin Sci Bul. 2013;58:3738-46.

48. Rögl F. Mediterranean and Paratethys. Facts and hypotheses of and Oligocene to Miocene palaeogeography (short overview). Geol Carphath. 1999;50:339-49.

49. Popov SV, Rögl F, Rozanov AY, Steininger FF, Shcherba IG, Kovac M. Lithological-paleogeographic maps of Paratethys: 10 maps late Eocene to Pliocene. Stuttgart: Courier Forschunginstitut Senckenberg; 2004.

50. Steininger FF, Rabeder G, Rögl F. Land mammal distribution in the Mediterranean Neogene: a consequence of geokinematic and climatic events. In: Stanley DJ, Wezel F-C, editors. Geological evolution of the Mediterranean Basin. New York: Springer Verlag; 1985. p. 559-71.

51. Garcés M, Krijgsman W, Agustií J. Chronology of the late Turolian deposits of the Fortuna basin (SE Spain): implications for the Messinian evolution of the eastern Betics. Earth Planet Sc Lett. 1998;163:69-81.

52. Krijgsman W, Hilgen FJ, Raffi I, Sierro FJ, Wilson DS. Chronology, causes and progression of the Messinian salinity crisis. Nature. 1999:400:652-5.

53. Krijgsman W, Langereis CG, Zachariasse WJ, Boccaletti M, Moratti G, Gelati R, et al. Late Neogene evolution of the Taza-Guercif Basin (Rifian corridor, Morocco) and implications for the Messinian salinity crisis. Mar Geol. 1999; 153:147-60.

54. Mesquita N, Cunha C, Carvalho GR, Coelho MM. Comparative phylogeography of endemic cyprinids in the south-west Iberian peninsula: evidence for a new ichthyogeographic area. J Fish Biol. 2007; 71 (Suppl A):45-75.

55. Cahuzac B, Alvinerie J, Lauriat-Rage A, Montenat C, Pujol C. Palaeogeographic maps of the northeastern Atlantic Neogene and relation with the Mediterranean Sea. Paleontol Evol. 1992;24-25:279-93.

\section{Submit your next manuscript to BioMed Central and we will help you at every step:}

- We accept pre-submission inquiries

- Our selector tool helps you to find the most relevant journal

- We provide round the clock customer support

- Convenient online submission

- Thorough peer review

- Inclusion in PubMed and all major indexing services

- Maximum visibility for your research

Submit your manuscript at www.biomedcentral.com/submit

) Biomed Central 